\title{
Community Perception of Chronic Kidney Disease in Supebeda, Chhattisgarh
}

\section{IJCRR \\ Section: Healthcare \\ ISI Impact Factor \\ (2020-21): 1.899 \\ IC Value (2020): 91.47 \\ $\operatorname{SJIF}(2020)=7.893$ \\ (c) (i) (3) \\ Copyright@IJCRR}

\section{Vinay Rathore ${ }^{1}$, Rahul Pal ${ }^{2}$, Abhiruchi Galhotra ${ }^{3}$, Saurabh Nayak ${ }^{1}$, Snehalata ${ }^{4}$ Vivekanand Jha $^{5}$, Nitin M Nagarkar ${ }^{6}$}

'Assistant Professor, Department of Nephrology, AllMS Raipur, India; ${ }^{2}$ Assistant Professor, Department of Community Medicine, BRLSABVM

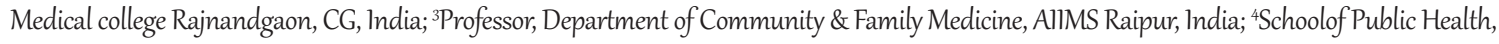
AllMS Raipur, India; ${ }^{5}$ George lnstitute for Global Health, New Delhi, lndia, 'Director and CEO, AllMS Raipur, India.

\section{ABSTRACT}

Introduction: An unusual number of Chronic kidney disease (CKD) cases have been reported from the village of Supebeda of district Gariyaband in Chhattisgarh. Recent studies have shown that the clinical profile of CKD patients in this village fits into the profile of CKD of Unknown Origin (CKDu).

Objectives: We conducted this study to explore the perception of the community about CKD in Supebeda.

Material \& Methods: This study was undertaken as a part of the outreach initiative of the Health Department of the Government of Chhattisgarh from October 2019 to January 2020. We conducted six In-depth Interviews (IDI) on a purposive sample of CKD patients and one Focus Group Discussion (FGD) with 11 mitanins (ASHA workers). Interviews were audio-recorded and transcribed verbatim. Data was analyzed manually using discourse analysis.

Results: All six respondents of IDI were farmers and had nonspecific symptoms of body aches, loss of appetite \& weakness. They sought treatment from private practitioners from the nearby state of Odisha because of proximity and preferred to go to Raipur only when they needed advanced treatment. The majority of these patients had received analgesics, herbal and ayurvedic drugs from rural practitioners. The study also revealed stigmatization of the village because of this disease. The participants of FGD were of opinion that CKD in the village was due to consumption of contaminated water and that it has led to ostracization of the village and reduced opportunity to get employment for the people of Supebeda.

Conclusion: We document community perception and health-seeking behavior of a remote village in Chhattisgarh state with a high prevalence of CKD. The study revealed a strong influence of socio-economic determinants, the influence of local myths, difficulties in accessing healthcare and stigma associated with kidney disease.

Key Words: Chronic kidney diseases, Supebeda, CKDu, Perception, Community, Village

\section{INTRODUCTION}

The public health importance of chronic kidney disease (CKD) due to its increasing burden and high cost of treatment has been recognized in recent years. The Global burden of disease study has shown that while the main drivers of CKD around the world are diabetes, hypertension and glomerular disease, ${ }^{1}$ a large proportion of CKD in low and low middle-income countries are caused by indiscriminate use of nephrotoxic drugs, herbal medications, toxins and infections.

A high prevalence of $\mathrm{CKD}$, primarily amongst rural communities engaged in agricultural work, has been observed in select geographical areas in several countries (El Salvador, Nicaragua, Costa Rica, Egypt, Sri Lanka and India) over the past two decades. ${ }^{2}$ CKD in these select demographics cannot be attributed to the known/traditional risk factors. The generic term "Chronic Kidney Disease of Unknown Etiology (CKDu)" has been used to describe this entity since the early 2000 s. $^{3}$

In India, this condition has been described from coastal villages of the Srikakulam district in Andhra Pradesh and parts of Odisha. ${ }^{4} \mathrm{~A}$ variety of hypotheses, including prolonged dehydration leading to heat stress, heavy metal toxicity, pesticide exposure, snake bite and genetics, have been proposed. ${ }^{2}$

Recent media reports have highlighted the high burden of CKD in Supebeda village of Gariyaband district, Chhattisgarh state in central India (Figure1), with reports of

\section{Corresponding Author:}

Dr. Abhiruchi Galhotra, Professor, Department of Community \& Family Medicine, AIIMS Raipur, India.

Email: abhiruchigalhotra@aiimsraipur.edu.in

ISSN: $2231-2196$ (Print)

Received: 07.10 .2021
ISSN: 0975-5241 (Online)

Revised: 28.10 .2021
Accepted: 15.11 .2021 
many deaths since 2009 . One report estimated that over 100 people out of the total population of 1182 had advanced CKD in the village. ${ }^{5}$ The issue of deaths suspected to be due to CKD in this village has been highlighted in media and has been raised in state assembly. ${ }^{6} \mathrm{~A}$ recent study has shown that the clinical profile of CKD patients in this village fits into the profile of $\mathrm{CKDu} .{ }^{7} \mathrm{The}$ reports also talk about anxiety, fear and sense of uncertainty in the minds of people about the nature of this disease and its causative factors.

With the global nephrology community increasing the focus on patient-centric approaches, this study was carried with the aim to understand the perception of the people of Supebeda regarding kidney diseases.

\section{MATERIAL \& METHODS}

This qualitative study was conducted between October 2019 and January 2020 as a part of the outreach initiative of the Health Department of the Government of Chhattisgarh to provide support to the people affected with CKD in Supebeda.

Focus group discussion (FGD) and in-depth interviews (IDI) were conducted to understand the community perspectives about the disease, its cause and its impact on people's health and livelihoods. Participants were selected using a purposive sampling method and included patients diagnosed with kidney disease, community leaders and frontline health workers (Mitanin).

Semi-structured interviews were used to collect data. Initially, participants were explained the purpose of the visit. All interviews were conducted face to face. Each interview began with an open-ended question.

The content of these interviews explored the causes of kidney diseases, symptoms, food habits, means of livelihood, addiction history, pesticide use, preventive and control measures of the disease, complications of the disease, health-seeking behaviour and the response of the government.

The interviews were conducted in the local language (Hindi), audio recorded, and transcribed verbatim. Transcripts were checked to ensure that they did not contain any mistakes. The transcripts in Hindi were subsequently translated into English by bilingual interviewers and reviewed by the research team. The data was analyzed manually (as the small number of transcripts did not require qualitative data analysis software), using the discourse analysis, which involves naturally occurring talks and all types of written texts. The themes identified are mentioned in table 1 .

\section{RESULTS}

A total of six IDIs were conducted with six patients with CKD (5 males and one female) and a focus group discussion was conducted with 11 Mitanins.

In-depth Interview: The findings of IDI are summarized in tables 1 and 2 . The interviews revealed that all the respondents perceived that CKD is caused due to contaminated water. All the respondents were of the opinion that the village faces stigmatization because of media highlights. We describe the perception of one of the patients as narrated.

"Sir, the main problem of kidney diseases is due to contaminated water and media highlight has led to stigmatization of village. People of other villages are afraid of marrying their sons and daughters due to stigma of kidney disease in the village." (CKD patient in his 50s)

Most of the patients had nonspecific symptoms like loss of appetite, weakness and body aches.

"I have had regular body aches, and itching all over the body, for almost a year" (A male CKD patient in his 40s)

"I have loss of appetite, episodes of vomiting \& fatigue most of the time" (A female patient of CKD in her 40s). "

Most of the respondents were regular consumers of tobacco, while some gave a history of frequent consumption of locally distilled alcohol.

"I have been chewing gudakhu for last 20-25 years". (A CKD patient in his 60s)

"I have been smoking bidi and sometimes drink locally brewed alcohol but now quit alcohol for last three month" (A CKD patient in his 30s). “

All respondents were farmers by occupation. Most of them were not able to work because of the illness. Many patients used analgesics for body aches.

"I am not working due to my illness, previously worked as a farmer for 15 years (A male CKD patient in his 50s)

Most of the respondents took herbal medications and ayurvedic drugs from local practitioners since the nearest medical facility is quite far. Some patients took treatment from the local community health centre. For specialized care, including dialysis, they travelled to the hospitals in Raipur, the state capital.

"I had been taking treatment from the hospital at Dharamgarh because the distance was hardly $2 \mathrm{~km}$ from Supebeda (A CKD patient in mid 50s.) (Dharamgarh is a town located in Odisha)"

"I went to Ramkrishna hospital (private hospital in Raipur) $250 \mathrm{~km}$ from our village because it requires dialysis. There is no facility of dialysis nearby and the dialysis machine at 
CHC, Deobhog, is not working."(A female patient in her 40s requiring dialysis).

Focus group discussion findings: The key issues discussed were sorted into three major themes of interest: Food and water, health-seeking behaviour and occupation.

Food and water: The participants were of the firm belief that kidney damage is because of the consumption of contaminated drinking water sourced from borewells. They felt it might be contaminated because they perceived its taste to be somewhat different, almost metallic. People felt that water should be drawn from a river close by - the 'Tel River' which contained 'pure water'. They also believed that the Alexandrite mine located near the village might also be responsible for kidney disease. Some unique eating habits were reported; breakfast generally consisted of a sweet dish (gulgula) in the morning. The previous day's cooked rice soaked in plain water overnight, known locally as "Maadh" was alsotaken as a meal.

Occupation: About two-thirds of the population of the village depend on agriculture or cattle grazing. A majority of people worked as unskilled farm labourers for daily wages. However, an increasing number were not able to work due to illness and were busy seeking treatment.

Health-seeking behaviour: Most of the villagers prefer going to private physicians in a nearby town, which is in a different state, Odisha. They did not see a reason to seek care in the state public health system because the closest facility was quite far - they would need to spend more time and money to get there. They often sought prescriptions for over-the-counter analgesics for body aches that would develop as a result of heavy manual labour. Interruptions in treatment were common, both because of temporary relief in symptoms and the high cost of treatment. They would take some ayurvedic medicines from local health practitioners. Several myths were prevalent - for example, pregnant women did not take folic acid and iron supplements, as it was perceived that these lead to big babies. They thought that a bigger-sized baby might create difficulties for normal delivery.

They pointed out that the water plant (fluoride-free water) set up by the state government two years ago was often not working because of a series of technical issues.

The villagers narrated several social problems, including ostracization of the village and reduced opportunity to get employment that involved manual labour. Interestingly, kidney disease was perceived to affect the 'marriage ability' of the local population, as families from outside the village were unwilling to enter into a matrimonial relationship with local residents because of perceived health issues.

\section{DISCUSSION}

Through this qualitative study, we describe the perception of the community of village Supebeda regarding the growing burden of CKD in the village and understand the healthseeking behaviour. Most of the reported issues were related to lack of access to essential needs - like clean drinking water, secure employment and essential healthcare. We confirmed the presence of social practices that give insights to their perceptions and health-seeking behaviour. A majority of the patients belonged to the agricultural occupation- they are directly exposed to chemical pesticides. Our findings suggest that while some patients raised serious concerns about the rising burden of CKD in the communities, the majority had a lack of awareness of its risk factors and adverse consequences. Although there was a strong suggestion that they blamed poor groundwater quality or local mining activity when asked for the basis, they were unable to provide supporting arguments. Studies from other regions of the world have reported poor knowledge and awareness of CKD amongst healthcare providers and patients, which aligns with our findings. ${ }^{9-11}$

Our findings also identify the major impact of socio-economic determinants on health-seeking behaviour and reasons for the delay in seeking medical advice. Lack of public health facilities nearby, the high cost of travel and treatment combined with the loss of income related to taking time off for medical treatment came out as important reasons for delayed diagnosis. Interruptions in treatment due to financial reasons and misperception that lack of symptoms indicate the absence of disease may also contribute to disease progression. The stigma associated with the diagnosis of kidney disease, which leads to social exclusion and loss of job opportunities, creates a vicious cycle of ill-health and poverty.

A number of social practices that can affect human health adversely, especially in the presence of other risk factors, were found to be common. This included tobacco use, use of overthe-counter pain killer medicines and consumption of herbs therapy. Our study showed an overall lack of awareness about the adverse health impact of these practices.

Finally, we found a general apathy and fatalistic attitude towards their health in the villagers, with the focus on livelihoods and social stigma leading to a neglect of health issues.

\section{CONCLUSION}

We document community perceptions and health-seeking behaviour of a village with a high prevalence of CKDu. The study revealed a strong influence of socio-economic determinants, the influence of local myths, difficulties in accessing healthcare, and stigma associated with kidney disease. Multi-pronged action is needed to influence awareness, 
change behaviour and develop a resilient healthcare system that can respond to the needs of the community

Limitation: Since this is a qualitative study with a limited sample size, the findings cannot be generalized unless they are combined with population-based quantitative research. Since, this study was done as a part of service delivery the sample size of our study for IDIs and FGDs was limited.

Ethical Approval: AIIMSRPR/IEC/2020/700 dated 19.12.2020.

\section{Source of Funding: Nil}

Conflict of Interest: The authors have no conflicts of interest associated with the material presented in this paper.

\section{ACKNOWLEDGEMENT}

We appreciate the collaboration of all participants, State health authorities Dr Netram Navratna (CMHO), Dr.SK Binjwar additional director and nodal officer Gariyabandh, Dr Sunil Bharti (BMO Deobhog CHC), Dr Jay Patel (PG MO, Gariyaband) other Senior Health officers as well as all the supports extended from the Directorate Health services, Raipur

\section{ORCID:}

Vinay Rathore: https://orcid.org/0000-0003-4315-5072

Rahul Pal: https://orcid.org/0000-0003-3542-1959

AbhiruchiGalhotra: https://orcid.org/0000-0001-6169-8527

VivekanandJha: https://orcid.org/0000-0002-8015-9470

Authors' Contribution: Dr Vinay Rathore, Dr Rahul Pal, Dr Abhiruchi Galhotra, Dr Saurabh Nayak, Ms Snehalata, Prof Vivekanand Jha, Prof Nitin M Nagarkar.

\section{REFERENCES}

1. GBD Chronic Kidney Disease Collaboration Global, regional, and national burden of chronic kidney disease, 1990-2017: a systematic analysis for the Global Burden of Disease Study 2017. Lancet.

2. Lunyera J, Mohottige D, Von Isenburg M,Jeuland M, Patel UD, Stanifer JW. CKD of Uncertain Etiology: A Systematic Review. Clin J Am Soc Nephrol.

3. Correa-Rotter R, Wesseling C, Johnson RJ. CKD of unknown origin in Central America: the case for a Mesoamerican nephropathy. Am J Kidney Dis.

4. Anupama YJ, Sankarasubbaiyan S, Taduri G. Chronic kidney disease of unknown etiology: Case definition for India - A perspective. Indian J Nephrol [Epub ahead of print] [cited $2020 \mathrm{Jul}$ 23]. Available fromhttp://www.indianjnephrol.org/preprintarticle.asp? $\mathrm{id}=266081$

5. Supebeda Village Population - Deobhog - Raipur, Chhattisgarh. [Internet]. Census2011.co.in. n.d. Available at: [Accessed 27 September 2020]

6. Indian express. Chhattisgarh government to examine genetic cause of kidney ailments that claimed 71 lives. Available at: https:/www.newindianexpress.com/nation/2020/jan/16/chhattisgarh-government-to-examine-genetic-cause-of-kidney-ailments-that-claimed-71-lives-2090433.html

7. Chowdhary, P., Rathore, V., Jain, K., Galhotra, A., Verma, N., Kale, S. et al., (2020). CKD of Unknown Origin in Supebeda, Chhattisgarh, India. Kidney international reports, 6(1), 210-214.

8. Ravishankar PL, Nadkerney P, Pramod V, Soni A, Jaiswal R, Kumar A, et al., Effect of Gudakhu (Smokeless Tobacco) on Periodontal Health: A Case-control Study. Int J Oral Care Res, 2017;5(2):87-90.

9. Choukem, S. P., Nchifor, P. K., Halle, M. P., Nebongo, D. N., Mboue-Djieka, Y., Kaze, F. F. et al., (2016). Knowledge of physicians on chronic kidney disease and their attitudes towards referral, in two cities of Cameroon: a cross-sectional study. BMC research notes, 9, 29.

10. Plantinga LC, Tuot DS, Powe NR. Awareness of chronic kidney disease among patients and providers. Adv Chronic Kidney Dis.

11. Lunney, M., Alrukhaimi, M., Ashuntantang, G. E., Bello, A. K., Bellorin-Font, E. et al.(2018). Guidelines, policies, and barriers to kidney care: findings from a global survey. Kidney international supplements, $8(2), 30-40$.

Table 1: Themes, Subthemes and codes in relation to CKD as extracted from In-depth interview

$\begin{array}{llll}\text { S. No } & \text { Thematic category } & \text { Subcategories } & \text { Extracted codes } \\ 1 & \text { Perception } & \text { a) Related to cause of disease } & \text { a) Contaminated water } \\ & & & \text { b) Not getting water from Tel river } \\ & & \text { c) Mines as a cause of CKD }\end{array}$
b) Stigmatization
c) Hardship

2

Symptoms

3 Addiction history

$4 \quad$ Livelihood means

a) Tobacco use

b) Alcohol drinking

a) Farmer

b) Farm labourer a) Media highlight has increased their problem

a) Death of sole breadwinner

b) Not able to work because of illness

a) Loss of appetite, weakness, burning micturition, pain \& itching

a) Most of the participants chew Tobacco

a) Some participants regularly consume alcohol

a) All the participants were involved in agricultural activities 
Table 1: (Continued)

\begin{tabular}{|c|c|c|c|c|}
\hline S. No & Thematic category & Subcategories & Ex & racted codes \\
\hline \multirow[t]{6}{*}{5} & \multirow[t]{6}{*}{$\begin{array}{l}\text { Health seeking behav- } \\
\text { iour }\end{array}$} & a) Treatment initiation & a) & $\begin{array}{l}\text { People seek medical advice only when they could } \\
\text { not work properly. }\end{array}$ \\
\hline & & & b) & $\begin{array}{l}\text { They also used pain killers to feel better and } \\
\text { work }\end{array}$ \\
\hline & & & c) & $\begin{array}{l}\text { Border of Odisha is about } 1-1^{1 / 2} \text { kilometre, the } \\
\text { patients prefer to go there for health care because } \\
\text { of close proximity }\end{array}$ \\
\hline & & & d) & $\begin{array}{l}\text { People use to take ayurvedic and herbal medi- } \\
\text { cines }\end{array}$ \\
\hline & & b) Treatment Compliance & a) & $\begin{array}{l}\text { Stop taking medicines once symptoms subside } \\
\text { and feel better. }\end{array}$ \\
\hline & & & b) & $\begin{array}{l}\text { Poor compliance in patient with long duration of } \\
\text { treatment }\end{array}$ \\
\hline
\end{tabular}

Table 2: Findings of In-depth interviews

\begin{tabular}{|c|c|c|c|c|c|}
\hline & Perception & Symptoms & Addiction History & Livelihood Means & Health Seeking Behaviour \\
\hline $\mathrm{P}(1)$ & $\begin{array}{l}\text { 1. Kidney's are dam- } \\
\text { aged because of } \\
\text { contaminated } \\
\text { water } \\
\text { 2. Media highlight } \\
\text { has increased their } \\
\text { problem (stated } \\
\text { by all patients) }\end{array}$ & $\begin{array}{l}\text { 1. Body aches } \\
\text { 2. Burning micturi- } \\
\text { tion } \\
\text { 3. itching all over the } \\
\text { body } \\
\text { 4. swelling }\end{array}$ & $\begin{array}{l}\text { Consumption of } \\
\text { gutka since last } \\
10-15 \text { yrs }\end{array}$ & $\begin{array}{l}\text { Totally depends on } \\
\text { cattle }\end{array}$ & $\begin{array}{l}\text { Taking treatment from near- } \\
\text { by hospital (CHC, Deobhog) }\end{array}$ \\
\hline $\mathrm{P}(2)$ & & $\begin{array}{l}\text { 1. loss of appetite, } \\
\text { 2. episodes of vomit- } \\
\text { ing } \\
\text { 3. fatigue most of the } \\
\text { time }\end{array}$ & $\begin{array}{l}\text { Chew tobacco since } \\
15 \text { years and drink } \\
\text { alcohol occasion- } \\
\text { ally }\end{array}$ & $\begin{array}{l}\text { Not working due to my } \\
\text { illness, previously he } \\
\text { worked as a farmer in } \\
\text { the past for } 15 \text { yrs }\end{array}$ & $\begin{array}{l}\text { Taking treatment from } \\
\text { Ramkrishna hospital (private } \\
\text { hospital) because it requires } \\
\text { dialysis also. }\end{array}$ \\
\hline $\mathrm{P}(3)$ & & No symptoms & $\begin{array}{l}\text { Chew gudakhu\# } \\
\text { forlast } 20-25 \text { years }\end{array}$ & Farmer & $\begin{array}{l}\text { Taking treatment from } \mathrm{CHC} \\
\text { Deobhog }\end{array}$ \\
\hline $\mathrm{P}(4)$ & & $\begin{array}{l}\text { 1. back pain } \\
\text { 2. Pain lower ex- } \\
\text { tremities since 6-8 } \\
\text { months }\end{array}$ & $\begin{array}{l}\text { No alcohol and } \\
\text { tobacco use }\end{array}$ & construction worker & $\begin{array}{l}\text { Didn't go to hospital because } \\
\text { of work, taking treatment } \\
\text { from medical store. }\end{array}$ \\
\hline $\mathrm{P}(5)$ & & $\begin{array}{l}\text { 1. disturbed sleep at } \\
\text { night due to urina- } \\
\text { tion, } \\
\text { 3. swelling in lower } \\
\text { extremities since } \\
\text { 2-3 months }\end{array}$ & $\begin{array}{l}\text { Cigarettes and } \\
\text { sometimes drink } \\
\text { locally brewed } \\
\text { alcohol but now } \\
\text { quit alcohol since } 3 \\
\text { months }\end{array}$ & $\begin{array}{l}\text { Patient did not re- } \\
\text { spond. }\end{array}$ & $\begin{array}{l}\text { Taking treatment from near- } \\
\text { by hospital Dharamgarh(the } \\
\text { distance was hardly } 2 \text { kms } \\
\text { from their village Supebeda } \\
\text { and it is located in Odisha) }\end{array}$ \\
\hline$P(6)$ & & $\begin{array}{l}\text { 1. swelling in lower } \\
\text { extremities followed } \\
\text { by } \\
\text { 2. generalized } \\
\text { weakness all over } \\
\text { the body since } 6 \\
\text { months }\end{array}$ & $\begin{array}{l}\text { Smoke and chew } \\
\text { tobacco in the past } \\
\text { and presently quit } \\
\text { since } 2 \text { years be- } \\
\text { cause of my illness. }\end{array}$ & $\begin{array}{l}\text { He is not working } \\
\text { since } 7-8 \text { months due } \\
\text { to illness; initially he } \\
\text { worked as a farmer. }\end{array}$ & $\begin{array}{l}\text { Ayurvedic medications taken } \\
2 \text { years back but symptoms } \\
\text { did not resolve so shifted to } \\
\text { allopathic medicines. (Private } \\
\text { facilities i.e. Ramkrishna } \\
\text { hospital) }\end{array}$ \\
\hline
\end{tabular}

\# Gudakhu is a paste- like substance, a mixture of tobacco, molasses, jaggery, and red kharia (a form of soil), widely consumed in Chhattisgarh, Odisha, Jharkhand. ${ }^{8}$ 


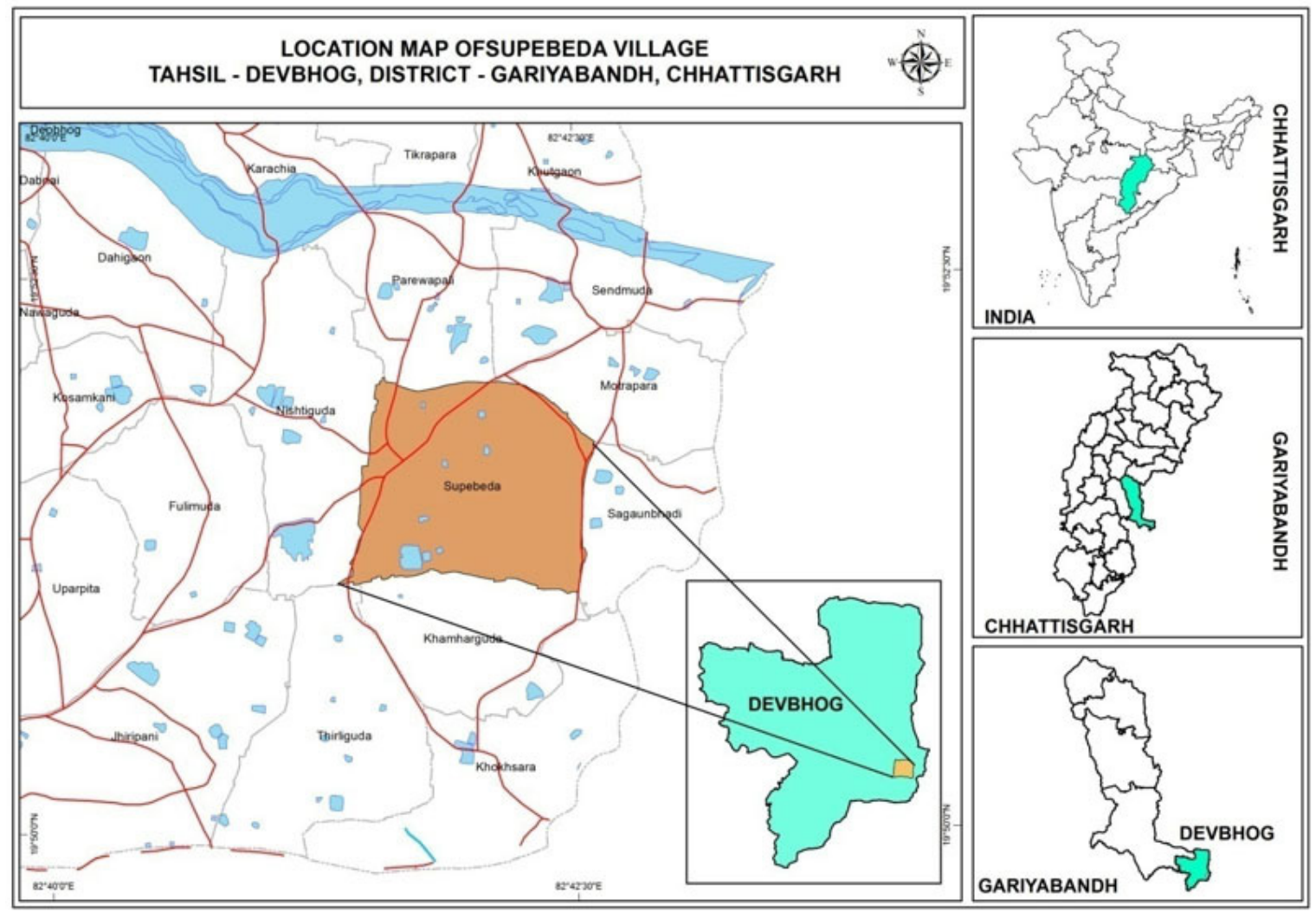

Figure 1: Map showing the Location of Supebeda. 